\title{
HISTOLOGICAL AND HORMONAL TESTICULAR CHANGES IN SPINAL CORD PATIENTS
}

\author{
By A. Leriche ${ }^{\star}$, E. Berard ${ }^{\star}$, J. L. Vauzelle†, P. Minaire*, R. Girard, \\ J. P. ARCHIMBAUd ${ }^{\star}$ and J. Bourret \\ * Hôpital Henry Gabrielle, Université Claude Bernard, 69230 Saint-Genis-Laval \\ † Laboratoire d'Anatomie Pathologique, Hôpital de la Croix-Rousse, France
}

Abstract. Hormonal dosages and testicular biopsy are discussed in paraplegic patients of several neurological levels. There are no absolute biological criteria but histology showed slowing of spermatogenesis.

Key words: Testicular biopsy; Spermatogenesis.

\section{Materials and Methods}

WE studied 57 cases of paraplegia among patients aged I6 to 66, at any neurologic level, either complete or incomplete, in order to find out whether there were any testicular alterations, which could lead to histo-hormonal correlations.

Wherever it was possible the following investigations were made: $(a)$ the static hormonal dosage in urine of the I7 ketosteroids with chromatography of testosterone; $(b)$ the dynamic dosage of the same hormones after an adrenal blockage with dexamethasone and after testicular stimulation with gonadotrophin during restraint; and $(c)$ a dosage of $\mathrm{FSH}$ and ICSH was carried out in blood whenever possible. To do so, we resorted to the radioimmunologic techniques.

The surgical techniques of the testicular biopsy are simple: without anaesthesia or after application of a local anaesthetic, a vertical cut of all the envelopes of the scrotum including the albuginea are made. Once all the envelopes have been fixed by a guide thread, pressure on the testicle and a simple excision of a tissular fragment is carried out: complete and compressive of the albuginea with an $\mathrm{X}$-shaped stitch follows. Closure of the envelopes with silk. The biopsy lasts 5 min and is carried out unilaterally.

A spermogram was done in I I cases only, because some patients refused it. In five cases, a spermogram was practised after an intraspinal injection of prostigmine.

\section{Hormones}

\section{Results}

Static rates. The $\mathrm{I} 7$ ketosteroids were normal in 50 cases out of 54 .

Testosterone (Fig. I) was I6 times lower or slightly lower than the average rate, and 26 times normal or slightly higher than the average rate.

Dynamic dosages. The stimulation of the testicle did not involve alterations of the I 7 ketosteroids but led to an increased rate of testosterone in 22 cases out of 35 . Yet the adrenal restraint was positive in 33 cases out of 38 for the 17 ketosteroids, while it was negative in 20 cases out of 33 for testosterone.

The gonadotrophins. The rates were not characteristic: the FSH (folliclestimulating hormone) was high nine times, low eight times and normal seven times; 


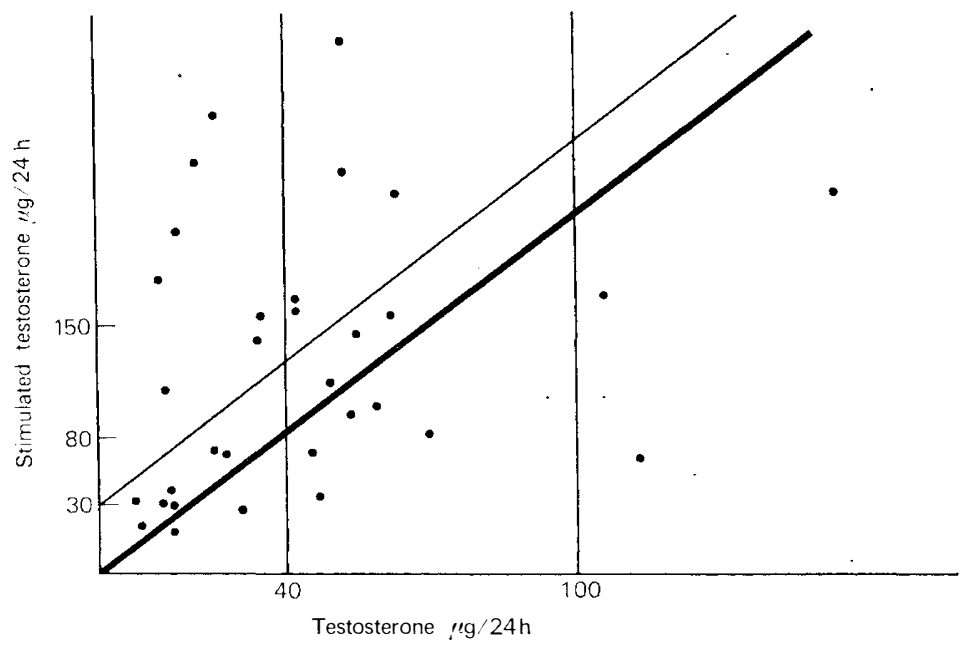

FIG. I

Static and stimulated urinary testosterone. The diagonal lines show the areas of normal stimulation (50 to $150 \%$ ). The vertical lines represent the average rates of testosterone.

the ICSH (interstitial cells stimulating hormone) was high six times, low nine times and normal nine times.

\section{Biopsy}

In typical cases (Fig. 2). Either spermatogenesis did not exist, or its maturation stopped, in 50 per cent of the cases and the interstitial tissue was sclerosed in 64 per cent of the cases (with necrosis of the germ cells and obstruction of the tubes). It was the centre of oedema or of vascular sclerosis in 22 per cent of the cases. The Leydig cells were rare or hyperplastic in 32 per cent of the cases.

In other cases, i.e. the remaining 50 per cent (Fig. 3). Spermatogenesis was active, but also often simultaneous with a slowing or obstruction of tubes, the Sertoli cells were normal but hyperplasic. The interstitial tissue did not show any sign of sclerosis or oedema, and the Leydig cells were normal.

Spermogram. We carried out II spermograms, and eight of them showed azoospermia.

\section{Discussion}

The Picture of the Interstitial Tissue

There was no significant correlation with the clinical picture of paraplegia, nor with the hormonal rates and the activity of spermatogenesis. Indeed, spermatogenesis was active in I4 per cent, while there was sclerosis of the interstitial tissue. Therefore, it was not possible to conclude anything from the picture of the interstitial tissue.

\section{The Picture of the Leydig Cells (Fig. 4)}

The correlations with testosterone were worthwhile studying since this hormone is secreted by the Leydig cells. In 12 out of the 28 cases, when com- 

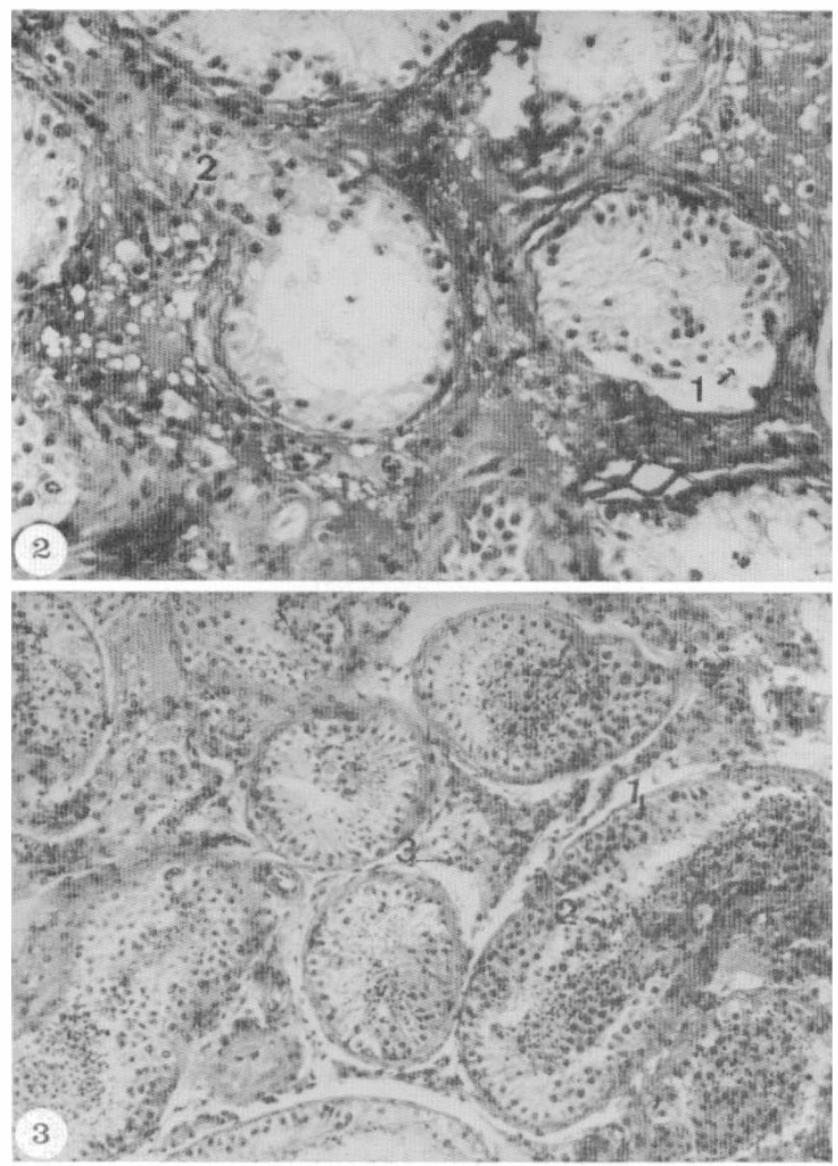

FIG. 2

A biopsy with a poor spermatogenesis (I), and a sclerosis of the interstitial tissue.

FIG. 3

A biopsy with a rather good spermatogenesis (I) but with an obstruction of tubes (2). There is no sclerosis of the interstitial tissue (3).

parison could be established, there was a dissociation. There was either a cellular damage with normal testosterone or a lowered rate of testosterone in spite of the normal appearance of the undamaged Leydig cells.

In those cases the comparison with the ICSH was interesting: when testosterone was low there was a correlation between a hypersecretion of ICSH and a normal or hyperplasic appearance of the Leydig cells, proving the feedback efficiency as well as the hypophysotesticular action, as if testes as a whole were no longer efficiently stimulated by ICSH.

In those cases, when there was bad correlation, the exogenic stimulation of ICSH, with rates that are clearly supraphysiological (5000 units of gonadotrophins during 3 days), started the secretion of testosterone again. 


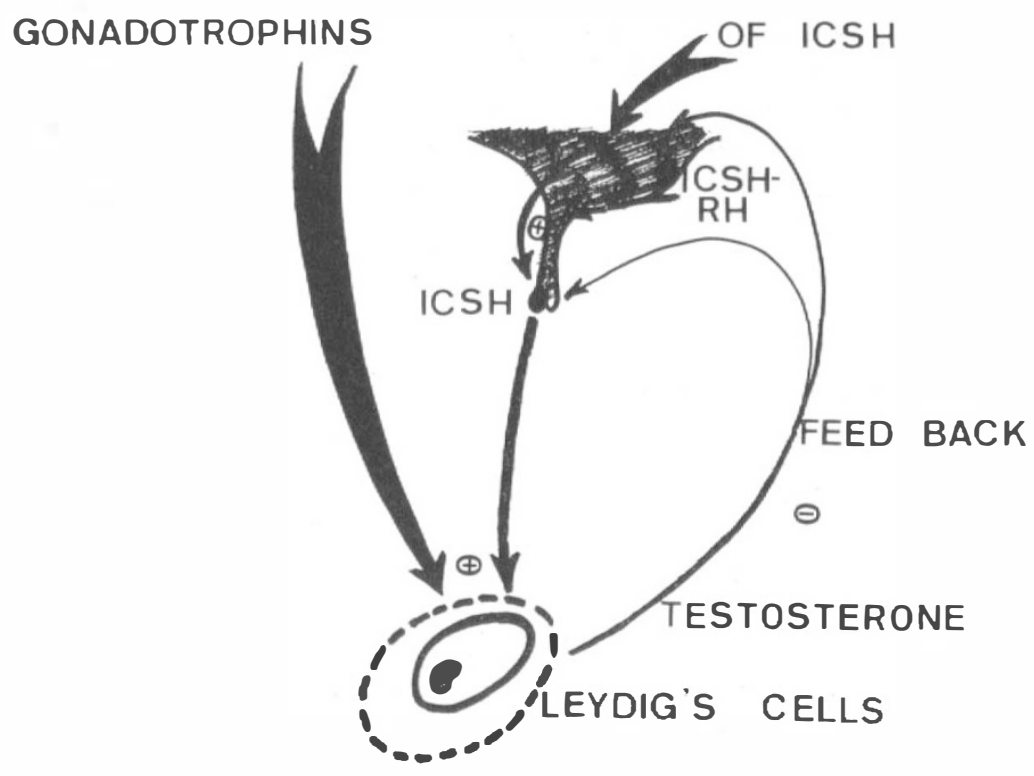

FIG. 4

Investigations on the hypothalamo-hypophysotesticular axis.

\section{The Action of the Eccrine Testicle}

Spermatogenesis: (I) There was no correlation with the rates of $\mathrm{I} 7$ ketosteroids which were always normal. (2) There was no significant influence of the rate of testosterone on spermatogenesis, but in all the cases when testosterone is low, there was no active spermatogenesis. (3) The rates of FSH were normal or low when spermatogenesis was active. (4) Spermatogenesis was inactive when ICSH rates were normal or high. (5) The spermogram was well correlated with the spermatogenesis. (6) The neurological condition-80 per cent of the incomplete syndromes had active spermatogenesis but only 40 per cent of the complete ones had active spermatogenesis. (7) The neurological level-the most interesting correlation was found between the Cauda Equina syndromes and the activity of the spermatogenesis in seven cases out of seven. In seven Cauda Equina cases spermatogenesis was active, while none of those patients had usual sexual activity. (8) Therefore, sexual activity does not interfere in a significant way. Moreover, only 36 per cent of the patients who had active spermatogenesis also had sexual activity.

\section{Conclusion}

In spinal cord injured patients, the neurogenic testicle does exist. It is histologically characterised by: a disappearing of spermatogenesis in 50 per cent of the cases; a sclerosis of the interstitial tissue in 64 per cent of the cases, and by constant anomalies of the tubes.

However, neither histology nor hormonology alone can lead to a prognosis. Only a spermogram is able to give an explicit indication, and without it we must resort to the most complete examinations: histological, hormonal (static and 
dynamic). This is the reason why our protocol now also includes a plasmatic dosage of testosterone as well as a stimulation of the FSH and ICSH by the releasing factors (ICSHRH TRH) and Prolactin. Spermatogenesis is neither dependent on the secretion of testosterone nor on the sexual activity. On the other hand, the neurological level (seven active spermatogenesis out of seven Cauda Equina) and also an incomplete paraplegia may interfere with alterations of spermatogenesis. High-level paraplegics who have regular sexual activity have rarely active spermatogenesis, while low-level paraplegics whose spermatogenesis is active have no erection.

\section{SUMMARY}

Among paraplegic patients at any neurological level, hormonal dosages and a testicular biopsy have been performed. There were no absolute biological criteria, but histology showed slowing of the spermatogenesis.

Patients at low levels had a good spermatogenesis. Sexual activity does not interfere in a significant way.

\section{RÉSUMÉ}

Les auteurs étudient les données cliniques, biologiques et histologiques concernant le testicule dans une population de blessés médullaires de tous les ages et de tous les niveaux neurologiques. S'il ne semble pas exister un critére biologique absolu, il existe par contre un caractére histologique dominant: la dimunition d'activité de la spermatogénése.

Le niveau neurologique semble jouer un role car les niveaux bas ont une bonne spermatogénése. L'activité sexuelle ne semble pas avoir de rapport avec la qualité de la spermatogénése.

\section{ZUSAMMENFASSUNG}

Die Autoren studierten die biologischen sowie histologischen Funktion der Samendrüssen in einer Zahl von verschieden en neurologischen Höhen bei Querschnittslähmungen. Ein genaue biologische Kriterium bestand nicht dagegen bestand eine Verminderung der Spermatogenesis. Das neurologischen Niveau scheint eine gewisse Rolle zu spielen. Die sexuelle Tätigkeit scheint ohne Verbindung mit der Qualität der Spermatogenese zu sein.

\section{REFERENCES}

Auroux, M. (1964). La spermatogénése, le sytéme nerveux central et le paraglégique. F. Urol. Nephrol. 80, 62 I-630.

Bors, E., Engle, T., Rosenquist, R. C. \& Holliger, V. H. (I950). La fécondité chez les hommes paraplégiques. Article préliminaire sur les études d'endocrinologie. F. Clin. Endocr. 10, 381-398.

Chapelle, P. A., Piera, J. B., Pannier, S., Lacert, P. \& Grossiord, A. (I974). Fonctions sexuelles et génitales des paraplégiques (á propos d'une étude de 165 dossiers). Ann. Med. Phys. 17, I-I3.

Guttmann, L. (I973). Comprehensive Management of Spinal Cord Injuries and Research. Blackwell, Oxford.

Hachen, H. J. (1973). Paraplégie et fonction sexuelle. Med. et Hyg. (Genéve), i4th Nov., 3I, No. I078, I753-I755.

Klein, M., Fontaine, R., Stoll, G., Dany, A. \& Frank, P. (I952). Modifications histologiques des testicules chez le paraplégique. Rev. Neurol. T.86, No. 5, 50I-503.

LERICHE, A. (I975). Les altérations du testicule dans les lésions médullaires. Correlations histohormonales. A propos de 50 biopsies testiculaires et de 50 bilans stéroidiens chez le paraplégique. Mémoire, 1975.

Lumbroso, P. (I96I). Les explorations de la function testiculaire. Rev. Prat. II, 279I2795 . 


\section{General Discussion}

Dr Cheshire (U.S.A.). This is a subject which is of great interest to me, and I will confess that I am frankly frightened of the prostigmine test. I've been worried too many times by it. The production of a specimen of sperm stimulation through a rectal electrode is easier but it still has its limitations. Testicular biopsy I think has great point but the question I would like to ask is that your group was a mixed group of complete lesions and incomplete lesions. Did you notice any difference between these two ? One would expect there to be a difference. Secondly, you did not give us any information as to whether these patients had gross persistent urinary infection, transient urinary infection or no infection. I would like to know if in particular the quality of the lesion and the quality or absence of infection were studied in your series.

DR BERARD. For the first question, I must say that 80 per cent of incomplete cases have a good spermatogenesis and only 40 per cent of complete cases have a good spermatogenesis. To the second question, I should say we have noted in our paper the subject of urinary infection and spasticity and so on. We cannot establish any correlation but we are not quite sure of that.

DR P. Dollfus (France). Could you specify how soon after the lesion you made those investigations?

DR BERARD. These biopsies were performed 3 months after injury. Now we perform them as soon as possible, in the Ist week if possible because we think that if we see some sign of spermatogenesis getting worse we must try to get sperm and to put it into bank.

DR RIDE (U.S.A.). We have done the same studies by evaluating the blood testosterone and by stimulation of the gonadotrophines and we found the same results like yours. The only precaution we had is the patients were not given any drug which acts on the hypothalamus such as Valium and barbiturates. I don't know whether you mentioned this precaution or not.

DR BERARD. Yes, that's right. 